------Jou. Raf. Sci., Vol. 21, No.1 pp 53- 64, 2010-------

\title{
Some Important Reactions of 4-Aminoantipyrine (4-AAP)
}

\author{
Shakir M. Saied \\ Department of Pharmacy \\ Institute of Technical \\ Mosul \\ E-mail:shakirmsaied@yahoo.com
}

\author{
Attalla M. Sheet \\ Moayed S. AL. Gwady \\ Department of Chemistry \\ College of Science \\ Mosul University
}

(Received 15/ 10/2009; Accepted 15/2/2010)

\begin{abstract}
The new heterocyclic compounds 1,5-Dimethyl-2-phenyl-4-(5-aryl-4,5-dihydro-1Hpyrazol-3-ylamino)-1,2-dihydropyrazol-3-ones (iiia-b) and 1,5-dimethyl-2-phenyl-4-(5-aryl4,5-dihydroisoxazol-3-ylamino)-1,2-dihydropyrazol-3-ones (iva-b) were synthesized in the first route in this work by refluxing ethanolic solution of hydrazine hydrate with $\mathrm{N}-(1,5-$ dimethyl-3-oxo-2-phenyl-2,3-dihydro-1H-pyrazol-4-yl)cinnamamid (iia) or (E)-3-(4chlorophenyl)-N-(1,5-dimethyl-3-oxo-2-phenyl-2,3-dihydro-1H-pyrazol-4-yl) acrylamide (iib) respectively. These unsaturated amides were prepared by the reaction of benzaldehyde or 4chlorobenzaldehyde with N-(1,5-dimethyl-3-oxo-2-phenyl-2,3-dihydro-1H-pyrazol-4yl)acetamide (i) in refluxing methanol. This acetamide was prepared by reaction of 4-AAP with acetyl chloride or with acetic anhydride.

In the second route 1,7-dimethyl-2-phenyl-hexahydro-6H-pyrazolo[4,3-e][1,2,4]triazine3,5-dione (vii) was synthesized by refluxing ethanolic solution of hydrazine hydrate (in presence of pyridine) with ethyl 1,5-dimethyl-3-oxo-2-phenyl-2,3-dihydro-1H-pyrazol-4ylcarbamate (vi). This carbamate was synthesized by the reaction of 4-AAP with pyridine or anhydrous sodium carbonate.

Finally, the reaction of 4-AAP with benzaldehyde or its 4-chloro derivative afforded the corresponding Schiff bases (va-b).

The structure of these compounds was confirmed by IR \& UV Spectra, in addition to the CHN elemental analysis.
\end{abstract}

Keywords: 4-Aminoantipyrine, pyrazole, oxazole, triazine

\section{4 -امينو الت بليرين المهمة}

\section{ll lل}

حضرت المركبت الحقية غير المتجلنسة الجيية 1 ،5 -ثنائي مثيل -2 - فنيل -4 - (5 -أري لـ -4 -5 -5 -

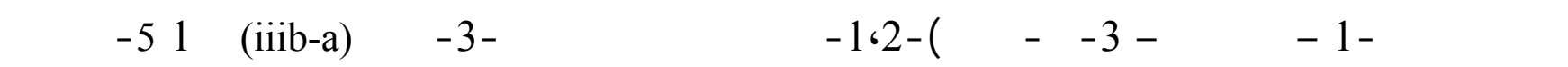

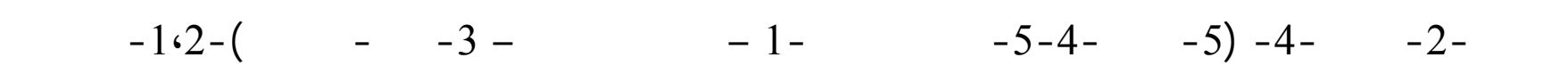
هيدروبايرازول -3 - اون (ivb-a) ضمن الظط الأول في هذا العطل ، بتصعيدمحلول ايث انوله للهي درازين 
المائي مع اللسينملميد (iia) أو الإريلاميد (iib) على التواله حيث حضرت الميدات غير المشبعة هذهمن

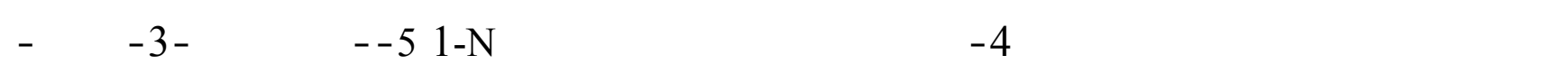

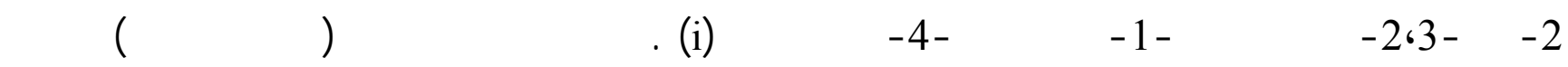

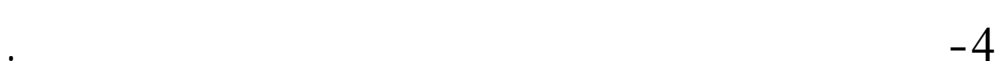

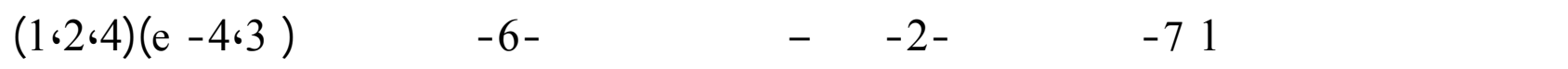

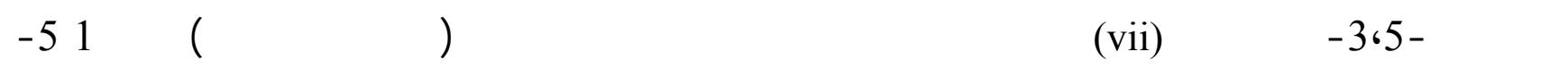

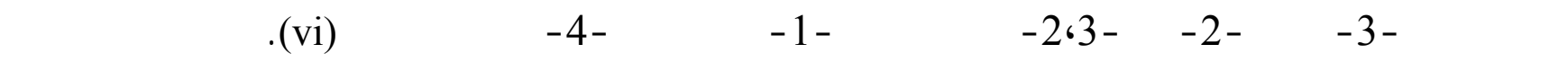

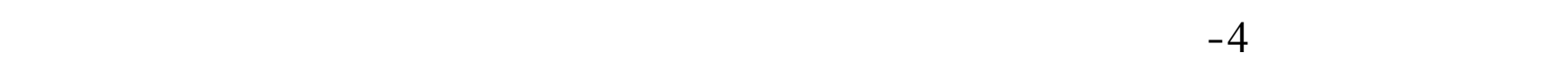
اللمائية. ولخيرا م تحضير قواعدشيف(va-b) من تفاعل 4 -المينو التق بـ ايرين م ع البززاليهائ د أوال ـ ـ 4 -

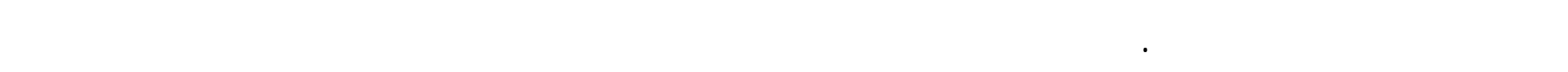
البفسجية إضفة إلىطريقة التحليل الدقيق لعناصر الكاربون والهيدروجين والنتروجين. 